\title{
Effect Of Capital, Liquidity, Efficiency, Performance On Profitability In Sharia Commercial Banks in Indonesia
}

\author{
R.Bambang. SM ${ }^{1}$, Moh. Sharil Bin Ahmad Razimi ${ }^{2}$ \\ STIE Krakatau Bandar Lampung ${ }^{1}$, Universiti Utara Malaysia ${ }^{2}$ \\ bsutrisno786@gmail.com ${ }^{1}$
}

\begin{abstract}
This research target aims to determine the effect of capital, liquidity, efficiency, banking performance on profitability in Islamic Commercial Banks in Indonesia in 2013-2015. This type of research is quantitative descriptive research. In this study using secondary data, and the period of time used 3 years, namely the period 20132015. The sampling technique was purposive sampling. The research variables consisted of 5 variables (4 independent variables and I dependent variable). The research data was taken from the 2013-2015 period Islamic financial bank II financial statements. Validation of this research data was verified by publishing on each Sharia Commercial Bank website, the website of Bank Indonesia and the website of the Indonesian Central Bureau of Statistics. Data analysis used is Regression analysis to analyze the factors that influence the profitability of Islamic Commercial Banks in Indonesia in 2013-2015. Data analysis method uses Multiple Regression. Hypothesis testing uses F-statistic test (F test), t-statistic test and determination of Ajusted $R^{2}$ coefficient with a significance level of $5 \%$. The results of the study are simultaneous independent variables ( $F$ test) that affect the profitability with a significant level of 0,000. While partially (t test) shows that: (I) capital has a positive and significant effect on profitability, (2) liquidity has a positive and significant influence on profitability, (3) efficiency has a negative and significant effect on profitability, (4) performance has a negative and significant influence on the profitability of Islamic Commercial Banks ..

Based on the adjusted $R^{2}$ obtained 0.563 this means that the ability of four independent variables can explain Profitability $56.30 \%$ while the remaining $43.70 \%$ is explained by other factors.
\end{abstract}

Keywords: Capital, Liquidity, Efficiency, Performance and Profitability

\section{A. INTRODUCTION}

The existence of banks/Islamic banking in Indonesia has been around for almost 30 years. The development of Islamic banking in Indonesia is indicated by the growth in the number of Islamic Commercial Banks (BUS), Sharia Business Units (UUS), and Sharia People's Financing Banks (BPRS). In 2015, there were I2 BUS, 22 UUS, and I63 BPRS. Whereas in 20I6, the number of BUS and UUS remained while the SRB increased to I65 BPRS. According to the OJK, Sharia banking intermediation is still running well, reflected in the Financing 
Effect Of Capital, Liquidity, Efficiency, Performance On Profitability In Sharia Commercial Banksin Indonesia

(R.Bambang. SMㄴ, Moh. Sharil Bin Ahmad Razimi²)

Deposit Ratio (FDR) for Sharia Commercial Banks (Sharia) and Sharia Business Units (UUS) at $87.45 \%$ and operating expenses and operating income $89.22 \%$ down $I 75$ basis points compared to the same period the previous year. And Islamic banking in the February 2017 period still grew positively from the capital side. In addition to the good prospects for the emergence of Islamic banks, it is also supported by Law Number 2I Year 2008 (OJK Report February 2017).

Today, the domestic and international environment where Sharia banking operates becomes increasingly challenging (Idris, etal, 20I I: I)

The presence of the 2015 ASEAN Economic Community (MEA) agreement is feared to be a threat because potential domestic markets will taken by competitors from other countries. In the 8th Anniversary of the Association of ExpertsIslamic economist, Dr. HalimAlamsyah (Deputy Governor of Bank Indonesia, 2012: 6) revealed that some parties feared the presence of the 2015 ASEAN Economic Community (MEA) agreement as a threat because potential domestic markets would be taken by competitors from other countries. These concerns were groundless if we were able to show high competitiveness.

Table I.I

Ranking of Sharia Financial Institutions Based on Assets

\begin{tabular}{|c|c|c|}
\hline Peringkat & Negara & Aset $(\$ \mathrm{M})$ \\
\hline $\mathrm{I}$ & Malaysia & $\$ 423,28$ \\
\hline 2 & Arab Saudi & $\$ 338, \mathrm{II}$ \\
\hline 3 & Iran & $\$ 323,30$ \\
\hline 4 & UAE & $\$ 140,29$ \\
\hline 5 & Kuwait & $\$ 92,40$ \\
\hline 6 & Qatar & $\$ 81,03$ \\
\hline 7 & Bahrai & $\$ 64,64$ \\
\hline 8 & Turki & $\$ 3 \mathrm{I}, \mathrm{I} 6$ \\
\hline 9 & Indonesia & $\$ 18,63$ \\
\hline I0. & Banglades & \\
\hline
\end{tabular}

Source: Maris Strategies \&theBanker, 2017

But when viewed from the ranking assets of Islamic financial institutionsIndonesia is ranked 9th with assets of $\$ 35.63(\$ \mathrm{M})$. Compared to other ASEAN countries, namely Malaysia, which ranks first with assets of $\$ 423.28(\$ \mathrm{M})$, assets of Islamic institutions in Indonesia are still inferior to assets of Islamic institutions in Malaysia. 
IKONOMIKA

Volume 3, No 2 (2018)

Table I.2

Rating of Islamic Financial Institutions Based on Income Before Taxes

\begin{tabular}{|c|c|c|c|}
\hline Rating & Institution & State & $\begin{array}{c}\text { Revenuebefore Tax } \\
(\$ \mathrm{M})\end{array}$ \\
\hline I & Al Rajhi Bank & Saudi Arabia & $\$ 1,823$ \\
\hline 2 & Dubai Islamic Bank & UAE & $\$ 786$ \\
\hline 3 & Bank Pasargad & Iran & $\$ 663$ \\
\hline 4 & Bank Rakyat People's & Malaysia & $\$ 613$ \\
\hline 5 & Cooperation Malaysia & & \\
\hline 6 & Qatar Rayan Bank & Qatar & $\$ 554$ \\
\hline 7 & Sina Bank Iran & Qatar & $\$ 226$ \\
\hline 8 & FaisalIslamicBankofEgypt & Egypt & $\$ 179$ \\
\hline 9 & Karafin Bank & Iran & $\$ 170$ \\
\hline I0 & IslamicBanksof Brunei & Brunei & $\$ 121$ \\
\hline Souree & & & \\
\hline
\end{tabular}

Source: Maris Strategies \& the Banker, 2016

In addition, if seen from table 1.2. Regarding the top ten ranking of Islamic Financial Institutions based on pre-tax income, Islamic banks from Malaysia are able to rank 4. This shows that the economies of scale of Indonesian Islamic banks are still inferior to Malaysian Islamic banks which will be the main competitors.

Whereas when compared to conventional banking, the Sharia banking market share is still low. Low market share also affects the low level of profitability of Islamic banking. This is shown in the graphic image as follows: 
Effect Of Capital, Liquidity, Efficiency, Performance On Profitability In Sharia Commercial Banksin Indonesia

(R.Bambang. SM ${ }^{1}$, Moh. Sharil Bin Ahmad Razimi²)

\section{Table I.3}

\section{Development of Market Share and Return on Assets (ROA) of Banking Sharia and Conventional Banking in Indonesia 2012-2016 Data Output and Input Bank Syariah and Konvensional( Juta Rp.)}

Sumber: Data diolah berdasarkan Laporan Keuangan Bank Konvensional dan Bank Syariah priode 20I2- 2016 yang dipublikasikan melalui www.bi.go.id

In accordance with graphical display I.2, the market share of Islamic banking is still growing but is experiencing a slowdown in growth. Although it

\begin{tabular}{|c|c|c|c|c|c|}
\hline & 2012 & 2013 & 2014 & 2015 & 2016 \\
\hline \multicolumn{6}{|c|}{ Panel A.Bank Konvensional } \\
\hline Deposit & 376.002 .416 & 431.076 .220 & 479.728 .795 & 57I.888.990 & 669.893 .884 \\
\hline Labor & 8.779 .597 & 9.886 .322 & 10.945 .000 & I3.07I.45I & I4.25I.053 \\
\hline Asset & $5 \mathrm{I0} 0.343 .08 \mathrm{I}$ & 556.545 .752 & 610.215 .289 & 725.716 .440 & 829.885 .425 \\
\hline Financing & 222.344 .040 & 253.593 .854 & 284.476 .529 & $35 \mathrm{I} .7 \mathrm{I} 0.73 \mathrm{I}$ & 464.045 .959 \\
\hline Income & I I.508.334 & 6.960 .488 & 9.016 .226 & I0.482.63I & I2.924.196 \\
\hline FDR & $0,59 \mathrm{I}$ & 0,588 & 0,593 & 0,615 & 0,693 \\
\hline \multicolumn{6}{|c|}{ Panel B. Bank Syariah } \\
\hline Deposit & I0.287.039 & I3.7I4.012 & I6.887.8I7 & 20.798.79I & 27.495 .903 \\
\hline Labor & I88.110 & 243.882 & 285.922 & 296.950 & 523.530 \\
\hline Asset & I2.508.254 & I6.703.617 & 19.922 .857 & 24.721 .122 & 32.756 .754 \\
\hline Financing & 9.706 .828 & I3.098.130 & I5.985.994 & 19.722 .258 & 27.098 .316 \\
\hline Income & I60.063 & $3 \mathrm{I} 0.3 \mathrm{I} 2$ & 384.458 & 430.002 & 607.596 \\
\hline \multicolumn{6}{|l|}{ FDR } \\
\hline \multicolumn{6}{|c|}{ Panel C. Bank Konvensional : Bank Syariah } \\
\hline Deposit & 36,55 & 31,43 & $28,4 \mathrm{I}$ & 27,50 & 24 \\
\hline Labor & 46,67 & 40,54 & 38,27 & 44,02 & 27,22 \\
\hline Asset & 48,80 & 33,32 & 30,63 & 29,36 & 25,33 \\
\hline Financing & $22,9 \mathrm{I}$ & 19,36 & 17,80 & 17,83 & 17,12 \\
\hline Income & 71,90 & 22,43 & 23,45 & 24,38 & 21,27 \\
\hline
\end{tabular}

increased in 2013 by $3.98 \%$ to $4.89 \%$ in 2013 , in 2014 it decreased to $4.85 \%$. Meanwhile, if viewed from the level of profitability of Islamic banking, the Return On Assets (ROA) is around $0.41 \%-1.94 \%$. The amount is still low when 
compared with the return on Assets (ROA) of conventional banking which ranges from $2.33 \%-3.11 \%$.

Therefore Sharia Commercial Banks in Indonesia are required to improve business performance and maintain banking system stability in the face of competition from domestic banks and foreign banks, both from conventional banking and Sharia banking itself. This is due to health and sustainability Bank profitability is vital in maintainingbanking system stability (Idris, etal, 20II: I).

The study of profitability is an important tool in improving performance, evaluating bank operations and determining management plans to assist in increasing bank opportunities to survive in competitive markets. Furthermore, studies on the profitability of Islamic banking are very important as a guide to improving the economy because banks contribute in economic growth and stability (Muda et al., 2013: 560).

One indicator used to measure the level of profitability is Return On Assets (ROA). ROA is the ratio between earnings after tax on total assets. This ratio reflects the ability of bank management to use its investment sources to increase revenue.

The determinant factors that influence profitability are divided into two categories, namely internal and external (Haron, 2004: 3). Internal reflection resulting from bank management decisions and policies can affect the bank's operational activities including profitability. According to Sufian and Parman (2009) in Idrisetal. (2013:2), bank-specific characters are internal determinants or internal factors which primarily affect the objects of management decisions and policies, such as capital adequacy, credit risk, liquidity, bank size, and expenditure management. Whereas external determinants are factorsconsidered beyond the control of bank management, such as competition, regulation, bank concentration, market share, capital scarcity, money circulation, bank size inflation and economic growth (Haron, I996; Petria et al., 2015).

Capital is a number of ownership funds available to support bank activities, besides that bank capital acts as a safeguard if it experiences adverse development (Idris, etal, 20II: 2). Capital adequacy ratio is used to measure the ability of bank capital to produce profitability.

Based on Smaoui and Salah's (20I2: 84) research, capital strength has a positive influence on the profitability of Islamic banks in the regional Gulf Cooperation Council (GCC). This is reinforced by Haron (2004) research; Naceur (2003); Petriaet.al (20I5); Smaoui and Salah (20I2); Vongand Chan (2006) which confirms capital has a significant effect on profitability. However, the results 
of the study are inversely proportional to the results of Abduh and Idrees (2013); IzharandAsutay (2007); Wasiuzzman and Tarmidzi (20I0), who found a negative relationship and insignificance between capital and profitability.

Liquidity is the ability of banks to pay obligations when the time period comes and this feature influences the level of liquidity risk associated with operations (Khanetl, 20I5: 75). According to research by Haron and Azmi (2004); Vong and Chan (2006); Wasiuzzaman and Tarmizi (2010),found a significant positive relationship between profitability and liquidity. But Izhar and Asutay (2007)found a negative relationship between liquidity and profitability because Islamic banking is more liquid than conventional banks.

Based on the background above, this study analyzes the effect of inflation, capital, liquidity, efficiency and performance on the profitability of Shariah Commercial Banks in Indonesia in 2013-20I5.

\section{B.THEORITICAL}

Health and sustainability of bank profitability are vital in maintaining banking system stability (Idrisetal.20II: I). Therefore, to improve performance, banks must maximize profits, reduce operating costs, and manage risk. Profitability is an important tool in improving performance, evaluating bank operations and determining management plans to help increase bank opportunities to survive in the market competitive. Furthermore, the study of the profitability of Islamic banking is very important as a guide to improving the economy because banks contribute to economic growth and stability. (Young et al.20I3: 560).

The measure of profitability used is Return on Equity (ROE) for companies in general and ReturnonAsset (ROA) in the banking industry. According to Flaminietal. (2009) in Abduh and Yameen (2013: 206), ROA is a representation that is better than ROE because ROE analysis ignores the influencefinance.

\section{Capital of Sharia Commercial Banks}

Capital is part of the funds that banks can use in their daily activities. The important thing related to the problem of funds is how to carry out management activities. Fund management is the process of managing the collection and allocation of public funds and capital funds to effectively and efficiently obtain the objectives of Islamic banks (Muhammad, 20I4: 525). According to Haron and Azmi (2004: 8), the higher the amount of capital injected, the more certain customers will be and will place their deposits in the bank. With more depositsplaced,the bank hasmore capitalto be managed in the rangkan resulting in higherprofitability.

Capital adequacy is an important thing in the banking business. Banks that have a good level of capital adequacy show indicators as a healthy bank. Because the 
bank's capital adequacy indicates its condition which is expressed by a certain ratio called the Capital Adequacy Ratio (CAR) (Sinungan, I994: I3I).

Based on the Financial Services Authority Regulations contained in the Financial Services Authority Regulation Number 2I / POJK.03 / 2014 concerning Minimum Capital Requirements for Sharia Commercial Banks, the provision of capital is around 8\% - II\% of RWA (Risk Weighted Assets)

\section{Bank Liquidity}

Liquidity is the ability of banks to pay obligations when the time period comes and this feature influences the level of liquidity risk related to operations (Khan, 20I5: 75). The liquidity ratio is measured from financing to total deposits and short-term funding. This ratio shows the relationship between liquidity management and bank performance (Abduh and Idrees, 2013: 206). Profitexpected to be higher when a lot of deposits are channeled into financing.

According to van Greuning and Iqbal (20II: I46), liquidity risk arises when the bank's ability to match the period of assets and liabilities is disrupted.Based on research by Haron and Azmi (2004);Vong andChan (2006); Wasiuzzaman and Tarmizi (2010), show relationships positive and significant between liquidity and profitability.

\section{Efficiency}

Efficiency comparison between output (input) with input (input), or the amount produced from one input used. A company can be said to be efficient if it uses fewer units when compared to the number of input units used by other companies. (Permono and Darmawan, 2000; 2) measure the level of efficiency of a bank based on the ability of the bank to generate maximum profit at a certain level of output prices compared to the best operating bank profit level (bank best practice) in the sample.

\section{Financial performance}

Calculation of financial performance of Islamic banks according to Bank Indonesia Regulation No. 9/I / PBI / 2007 Concerning the Soundness Rating System of Commercial Banks Based on Sharia Principles, is the capital (capital) ratio, earning asset quality ratio (KAP), profitability ratio (earnings) Liquidity ratio (liquidity) and Sensitivias on market risk (sensitivity to market risk)

\section{Hypotesis}

a. Partially there is the influence of Capital, Liquidity, Efficiency,

b. Performance on Profitability.

c. Simultaneously or together there is the influence of Capital, Liquidity, Efficiency, Performance on Profitability 
Effect Of Capital, Liquidity, Efficiency, Performance On Profitability In Sharia Commercial

Banksin Indonesia

(R.Bambang. SM ${ }^{1}$, Moh. Sharil Bin Ahmad Razimi²)

\section{METHODOLOGY.}

\section{Research design}

The analysis of this research is descriptive and verification. and analytical too which consists of 2 types. First is the analysis tool for describe research variables that use StatisticsDeskrtiptif. Second, analysis tools to test research hypothesespredetermined namely using Structural Equation AnalysisModeling (SEM) and LISREL and other research tools in the form of SPSS.

2. Research sites

The unit of analysis of this study is Islamic Commercial Bank companiesin Indonesia

\section{Population and Samples}

The population and sample are taken from II Islamic banksin Indonesia. Data collection is obtained from monthly reportsSharia Commercial Bank companies include data on Capital, Liquidity, Efficient, Performance and Bank Profitability value for 3 years (36 months) from2013-2015 period.

\section{Test of Research Instruments}

Instrument testing is done by testing the level of validity and reliability. The results of this test state that all question itemsis not valid because of the product moment correlation valuehas been corrected under the Corrected Item Total Correlation column below product moment correlation value table that is using $\mathrm{n}=36$ andalpha $5 \%$ is known to be 0.43 According to the current value of less than 0.70 less reliable After validity testing, reliability testing is done by comparingCronbach's Alpha value is 0.43 smaller than 0.70 . Withthus, the research questionnaire instrument is less valid and less reliable, so adjustments are needed.

\section{Data Analysis Method}

This study uses panel data analysis methods to analyzeThere are several steps taken, namely: (I) descriptive statistical analysis; (2) Partial test (t-Statistic Test), Simultaneous test (F-Statistic Test (3) regression equation analysis, and (4) hypothesis test.

\section{RESULTS AND DISCUSSION}

Calculation of Influence Value between variablesThe path / structure equation in this research model is;

$$
\begin{aligned}
& \text { YI }=\text { PYIXI + PYIX2 + PYIX3 + PYIX4 } \\
& \text { YI }=-69,803+0,464 \text { XI + 0,866X2 - 0, I03 X3 - 0,680X4 }
\end{aligned}
$$


The value of the constant is $-69,803$ in the regression equation above indicates that Profitability (Y) will remain at - 69,803 without the influence of independent variables. If variable XI (Capital) increasing by I unit, the $\mathrm{Y}$ value will increase by 0.464 . If variabel $\mathrm{X} 2$ (Liquidity) increases by I unit then $\mathrm{Y}$ value (Profitability) will increase by 0.866 . If the variable $\mathrm{X} 3$ (Efisiens) decreases by I unit then $\mathrm{Y}$ value will decrease by 0.I03. Next if the variable X4 (Performance) reduced by I unit, the $\mathrm{Y}$ value (Profitability) will decrease by 0.680

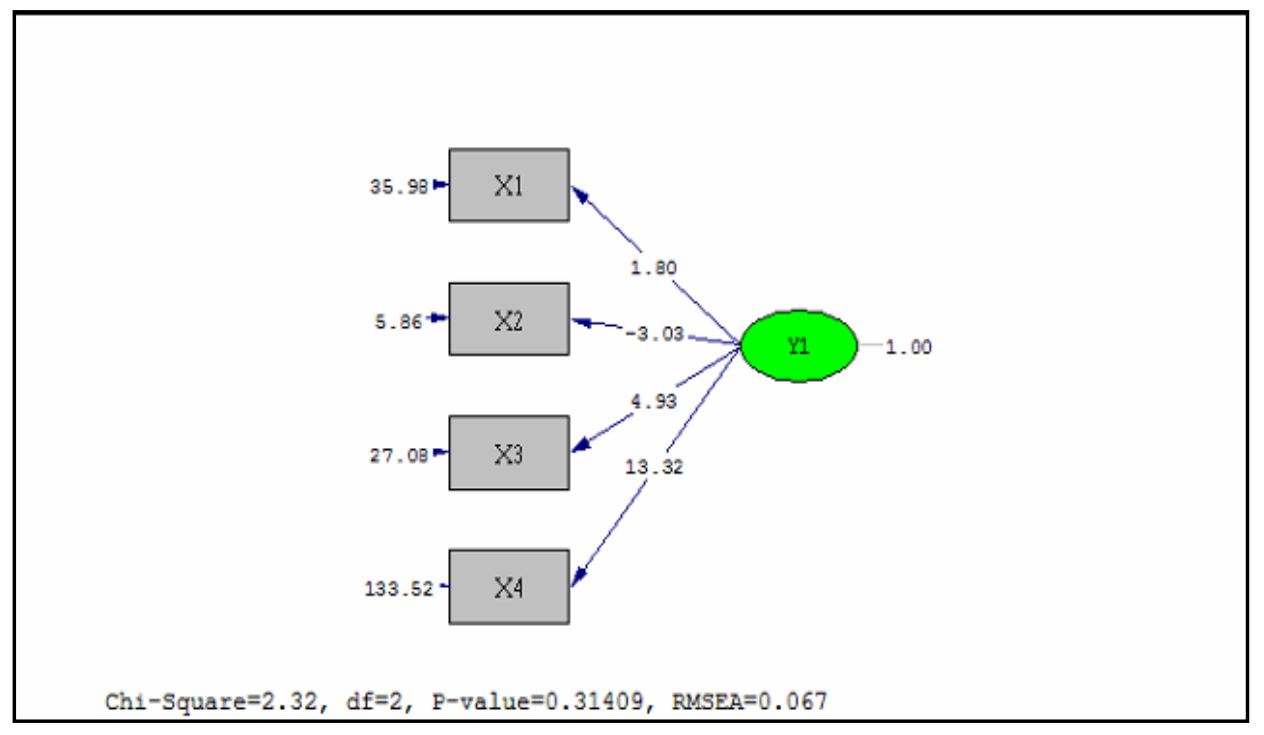

\section{Image I}

Complete Structural Model

\section{Calculation of direct influence}

\section{Direct Influence}

I. The influence of the variable capital (XI) on the variable profitability(YI) amounting to I.80

2. Effect of Liquidity variables (X2) on Profitability variable(YI) of - 3.03

3. Effect of Efficiency variable (X3) on Profitability variables(YI) of 4.93

4. The effect of the Bank Performance variable (X4) on the Profitability variable (YI) is I3.32

Thus it can be determined that the influence of Banking Performance and The efficiency of the profitability of Islamic Commercial Banks is greater than thatEffect of Capital and Liquidity on Sharia Commercial Banks on Profitability. 
Effect Of Capital, Liquidity, Efficiency, Performance On Profitability In Sharia Commercial Banksin Indonesia

(R.Bambang. SMㄴ, Moh. Sharil Bin Ahmad Razimi²)

\section{E. CONCLUSION}

I. There is a relationship of capital, liquidity, efficiency, simultaneous performance towards the profitability of Sharia Commercial Banks in Indonesia. Obtained the value of multiple correlation $(R)$ is $0.75 \mathrm{I}$ with a significance of 0,000 , which means it is proven that there is a relationship with strong and significant criteria. While the coefficient of determination ( $R$ sequare) of 0.563 or $56.3 \%$ means that the variables of capital, liquidity, efficiency and performance are able to explain the effect on profitability together at $56.3 \%$ while the remaining $43.7 \%$ is explained by other variables

2. That the influence of Banking Performance and Efficiency ongreater profitability (I8.25) than Capital Influence and Liquidity (-I2.30) in Islamic Commercial Banks for Profitability

\section{REFRENCES}

Abduh, Muhammad andYameen, Idrees.2013. Determinants of Islamic Banking Alamsyah, Halim.20 I2. Development and Prospects of Islamic Banking

And Financial Reporting, Vol.5, No. I, p. 75-90

Andi Van Greuning, Hennie and Zamirlqbal.20I I. Banking risk analysissharia. Jakarta: Salemba Empat

Banking:Evidence from Bank Muamalat Indonesia. Review of Islamic Commercial

Bank Assets Sharia and Sharia Business Unit. Jakarta: Economics, Vol. I I,

No. 2, p. 17-29

EU27 banking Systems.Procedia Economics andFinance, Vol. 20, p.5I8

Evidence from Malaysia and Pakistan. International Journal of Accounting Hakim, Abdul.2010. Descriptive statistics for economics and business.

Haron, 2004 Competition And Other External Determinants of TheProfitabilitof Hasan, M. Iqbal. 2002. The main material of research methodology and Indonesia: Welcoming the 2015 MEA. Delivered in the lecture Injection injection. http // kontan.co.id / news / modal-three-banksyariah-need-International Journal of Economics and Financial Issues Vol. 3 ,

Islamic Bank. Islamic conomicStudie, Vol. 4, No.I, p. 49-64 and Wan Islamic Banking Institutions' Profitability inMalaysia.World Applied Izhar, H., and M. Assutay, 2007. Observing the Profitability of Islamic Jakarta: Erlangga PublisherMankiw, N Gregory. 2003. Macroeconomic Journal of Finance and Economics, Vol. I, No.I, p. I-I8 
Karim, Adiwarm A.2007. Macroeconomics of Islam. Jakarta: PT Raja Grafindo Kuncoro,Mudrajad.2006. Strategy how to achieve excellencecompetitive.

London: The banker

Maris Strategies \& the Banker.20I5. Top Islamic Financial Institution

Marzuki. 2000. Research methodology. Yogyakarta: BPFE-UII

MIEI, I3 April20I2, www.bi.go.id

Muda etal.2013. Determinants of Islamic Banking Profitability in Malaysia.

Muhammad.20I4. Management of Islamic finance: fiqh and financial analysis.

Naceur, S.B., 2003. The Determinants of the Tunisian Banking Industry

Narbuko,Choliddan AbuAchmadi.2008. Research methodology. Jakarta: Bumi No.3,2013, p.559-569 Number I6 / POJK.03 / 2014 concerning Assessment of Quality of Nursofiza Wan Azmi. 2004. Determinants of Islam Bank Profitability. Global Obligations Minimum Islamic Commercial Banks. Jakarta: Persada Etc. 20I5.Gauging Profitability and Liquidity of Islam Banks:

Petria, Nicolae etal.2015. Determinants of Banks' Profitability:Evidence From Profitability in Malaysia. Australian Journal of Basic and Applied Profitability: Evidence Panel. University LibredeTunisWorkingpaper.

Sciences JournalI2 (Special Issue on BolsteringEconomic Sustainability), p.I-7 Sciences, Vol. 7, No. 2, p. 204-2I0 Scientific Association of Islamic Economic Experts (IAEI), 8th Anniversary of Script Financial Services Authority.20I5. June 2015 Islamic Banking Statistics.Jakarta: Financial Services Authority 2014. Service Authority RegulationFinance contained in the Financial Services Authority Regulation Number 2I / POJK.03 / 2014 concerning Capital Provision

Sinungan, Muchdarsyah.2000. Bank fund management.PT. Earth:JakartaScrip Smaoui, Houcem and Salah, InesBen.2012. Profitability of

IslamicBanks GCCRegion.Global Economy and Finance JournalVol.5, No.I, p.85-I02

Sugiyono.2009. Quantitative, qualitative, and R \& D research methods.

Contents: Alfabeta

Suliyanto. 20I I. Business research method. Yogyakarta: the application. Bogor:

Ghalia Indonesia Idris, et al. 20I I. Determinant of theory. Jakarta: Erlangga Suryanto, T., Purnamasari, F., \& Kurniawan, M. (2018). Tax Revenue and Disparity: How to Improvement Income Inequality in Islamic Perspective. Asian Journal of Social Sciences and Management Studies, 5(2), 65-7I. 
Effect Of Capital, Liquidity, Efficiency, Performance On Profitability In Sharia Commercial Banksin Indonesia

(R.Bambang. SM ${ }^{1}$, Moh. Sharil Bin Ahmad Razimi²)

Vong, AnaP.I., danH.Chan, 2009.Determinants of Bank Profitability in Macao University of Macao Working Paper

Wasiuzzaman, S., danH. Ahmed Tarmizi, 2010. Profitability of Islamic Banking Malaysia: An Empirical Analysis. Journal of Islamic Economics, Banking and Finance, Vol. 6, p. 4, p. 5I-68

Winarno, WingWahyu. 20I5. Econometric and statistical analysis witheviews. Yogyakarta: UPP STIM YKPN

Yudistira, Galvan.2015. The capital of three Islamic banks needs an 